\title{
Interpopulational Variation of NOR Positions and Karyotypic Analysis of Siamese Catfish (Pseudomystus siamensis) in Thailand
}

\author{
Weerayuth Supiwong ${ }^{1}$, Alongklod Tanomtong ${ }^{1 *}$, Arunrat Chaveerach ${ }^{1}$, \\ Tawatchai Tanee $^{2}$, Suthip Khakhong ${ }^{3}$, and La-orsri Sanoamuang ${ }^{1}$ \\ ${ }^{1}$ Applied Taxonomic Research Center (ATRC), Department of Biology, \\ Faculty of Science, Khon Kaen University, Khon Kaen, Muang 40002, Thailand \\ ${ }^{2}$ Faculty of Environment and Resource Studies, Mahasarakham University, \\ Mahasarakham, Muang 44000, Thailand \\ ${ }^{3}$ Aquaculture Program, Faculty of Agricultural Technology, \\ Phuket Rajabhat University, Phuket, Muang 83000, Thailand
}

Received May 31, 2012; accepted January 4, 2013

\begin{abstract}
Summary Interpopulational variation of nucleolar organizer region (NOR) position and karyotypic analysis of Siamese catfish (Pseudomystus siamensis) in Thailand were studied. The samples were taken from three locations ( 8 populations); the mitotic chromosome preparations were conducted directly from kidney cells. Conventional and Ag-NOR staining techniques were applied to stain the chromosomes. The results showed that the diploid chromosomes number was $2 n=50$ and the fundamental number (NF) was 96 in both sexes. The karyotype of $P$. siamensis showed two new cytotypes for this species. The chromosome of cytotype A and B showed the presence of metacentric, submetacentric, acrocentric and telocentric autosomes as 22-18-6-4 and 20-20-6-4, respectively, without any apparent sex chromosomal heteromorphism. Data obtained from chromosomal banding technique further suggests an interpopulation NOR polymorphism. Such variation is possibly caused by paracentric inversion. In addition, a pair of the long arms of chromosome pair 2' in cytotype A and chromosome pair $12^{\prime \prime}$ in cytotype B showed clearly observable NORs. The karyotype formulas of cytotype A and B for $P$. siamensis could be deduced as:

Cytotype A: $2 \mathrm{n}$ (diploid) $50=\mathrm{L}_{6}^{\mathrm{m}}+\mathrm{L}_{6}^{\mathrm{sm}}+\mathrm{L}_{2}^{\mathrm{a}}+\mathrm{M}_{16}^{\mathrm{m}}+\mathrm{M}_{12}^{\mathrm{sm}}+\mathrm{M}_{4}^{\mathrm{a}}+\mathrm{M}_{2}^{\mathrm{t}}+\mathrm{S}_{2}^{\mathrm{t}}$

Cytotype B: 2n (diploid) $50=\mathrm{L}_{2}^{\mathrm{m}}+\mathrm{L}_{6}^{\mathrm{sm}}+\mathrm{M}_{14}^{\mathrm{m}}+\mathrm{M}_{12}^{\mathrm{sm}}+\mathrm{M}_{6}^{\mathrm{a}}+\mathrm{M}_{2}^{\mathrm{t}}+\mathrm{S}_{4}^{\mathrm{m}}+\mathrm{S}_{2}^{\mathrm{sm}}+\mathrm{S}_{2}^{\mathrm{t}}$.
\end{abstract}

Key words Siamese catfish, Pseudomystus siamensis, Nucleolar organizer region, Polymorphism.

Thailand is one of the world's richest places of biodiversity, especially for freshwater fish species. With more than 700 species recorded, Thailand is one of the species diversity centers of the world (Vidthayanon 2005). Freshwater fish are especially important as they provide a high quality source of protein as food source for people who live near river basins. Fish in the family Bagridae, belonging to the order Siluriformes, are one of the most important fish consumed as food. Some species are kept as aquarium fish. The aquaculture of several species has recently become booming (Nelson 2006). For these reasons, they play an important role in the national economy.

An important characteristic of nucleolar organizer regions (NORs) in fish is inter- and intraspecies polymorphism. NOR characterization can be a cytogenetic marker for cytotaxonomic studies and can even aid in constructing phylogenetic hypotheses (cytosystematics) for several fish groups (Amemiya and Gold 1988, Galetti Jr 1998, Almeida-Toledo 2000). Some fish groups pres-

\footnotetext{
* Corresponding author, e-mail: tanomtong@hotmail.com

DOI: $10.1508 /$ cytologia. 78.25
} 


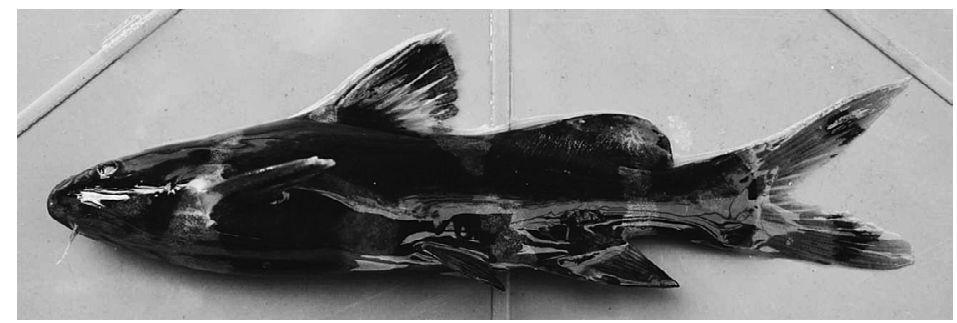

Fig. 1. General characteristics of the Siamese catfish, Pseudomystus siamensis (Siluriformes, Bagridae). Scale bar indicates $5 \mathrm{~cm}$.

ent a simple NOR system characterized by ribosomal cistrons on only one chromosome pair, whereas others have a multiple NOR system composed of cistrons dispersed over several chromosomes (Galetti Jr. 1998, Capistano et al. 2008).

There are five genera and 25 species in family Bagridae in Thailand, including Bagrichthys hypselopterus, Bag. macracanthus, Bag. macropterus, Bag. majusculus, Bag. obscurus, Batasio havmolleri, Bat. tengana, Bat. tigrinus, Hemibagrus filamentus, H. nemurus, H. wyckioides, $H$. wyckii, Mystus albolineatus, M. atrifasciatus, M. bocourti, M. castaneus, M. cavasius, M. multiradiatus, M. mysticetus, M. rhegma, M. singaringan, M. wolffi, Pseudomystus bomboides, P. siamensis (Fig. 1), and P. stenomus (Ferraris 2007, Rainboth 1996, Vidthayanon 2005).

There has only been one previous attempt at conventional staining analysis in $P$. siamensis from the Mekong basin, Nongkhai Province (five specimens), which detected the occurrence of one cytotype (Donsakul 2002). In the present work, a more detailed analysis is performed, involving Ag-NOR banding technique procedures to establish chromosomal marker, possibly including the nature of the rearrangements related to the present polymorphism. Moreover, the data provides useful basic information for conservation and breeding practices as well as analyses of chromosomal evolution in this species of fish.

Materials and methods

\section{Sample collection}

Specimens of $P$. siamensis (33 males and 33 females) were collected from eight populations of the Chi, Songkham, and Chao Phraya basins, Thailand (Fig. 2 and Table 1). The fish were transferred to laboratory aquaria and were kept under standard conditions for seven days prior to the experiments.

\section{Chromosome preparation}

Chromosomes were directly prepared in vivo (Chen and Ehbeling 1968, Nanda et al. 1995) as follows. Phytohemagglutinin (PHA) solution was injected to the abdominal cavities of the fish. 24 hours later, $0.05 \%$ colchicine solution was injected to the intramuscular and/or abdominal cavities of the fish. The treated samples were left $1-2 \mathrm{~h}$. Kidney and/or gill samples were removed and cut into small pieces before being mixed with $0.075 \mathrm{M} \mathrm{KCl}$. After all the large pieces of cells were discarded, an $8 \mathrm{ml}$ of cell sediments was transferred to a centrifuge tube and incubated for $25-35 \mathrm{~min}$. $\mathrm{KCl}$ was discarded from the supernatant after centrifugation at 1,200 rpm for $8 \mathrm{~min}$. Cells were fixed in fresh cool fixative ( 3 absolute methanol : 1 glacial acetic acid). The fixative was gradually added up to $8 \mathrm{ml}$ before centrifuging again at $1,200 \mathrm{rpm}$ for $8 \mathrm{~min}$ and the supernatant was discarded. The fixation was repeated until the supernatant was clear and the pellet was mixed with $1 \mathrm{ml}$ fixative. The mixture was dropped onto clean and cold slides by a micropipette, after which slides 
were left to dry following the air-dry technique.

\section{Chromosome staining}

Conventional staining was done using 20\% Giemsa's solution for $30 \mathrm{~min}$, and Ag-NOR banding was performed by adding 4 drops of $50 \%$ silver nitrate and $2 \%$ gelatin on slides, respectively. The slides were then sealed with cover glasses and incubated at $60^{\circ} \mathrm{C}$ for $5 \mathrm{~min}$. After that the slides were soaked in distilled water until cover glasses were separated and stained with $20 \%$ Giemsa's solution for $1 \mathrm{~min}$ (Howell and Black 1980).

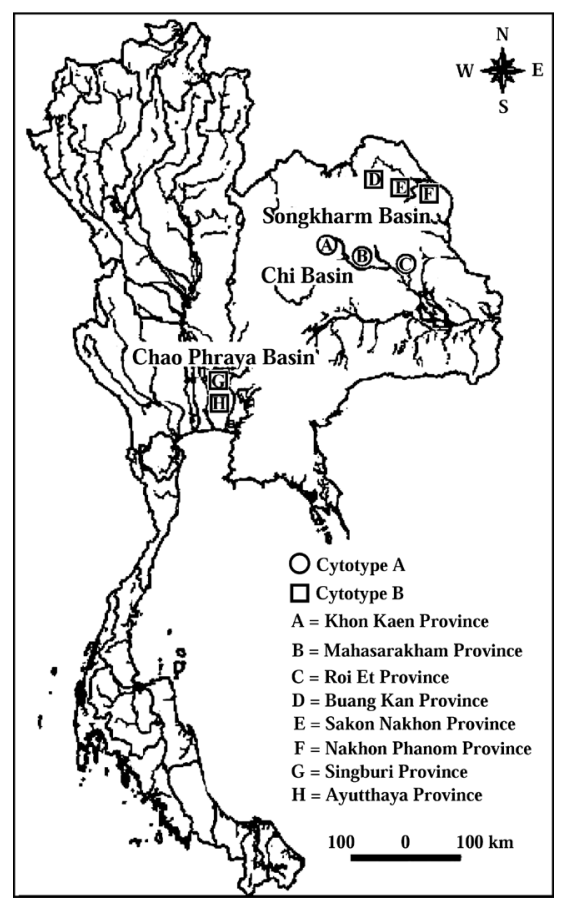

\section{Chromosome checks}

Chromosome counting was performed on mitotic metaphase cells under a light microscope. 20 clearly observable and well-cells spread chromosomes of each male and female were selected and photographed. The length of short arm chromosome (Ls) and long arm chromosome ( $\mathrm{Ll}$ ) were measured to calculate length of total arm chromosome (LT, LT=Ls+Ll). The relative length $(\mathrm{RL})$, the centromeric index $(\mathrm{CI})$, and standard deviation (SD) of RL and CI were estimated (Chaiyasut 1989). The CI (q/p+q) between $0.50-0.59,0.60-0.69,0.70-0.89$, and 0.90-0.99 are described as metacentric, submetacentric, acrocentric and telocentric chromosomes, respectively. The fundamental number (NF) was obtained by assigning a value of two to metacentric, submetacentric and acrocentric chromosomes and one to telocentric chromosomes. All parameters were used in karyotyping and idiogramming.

Fig. 2. Map of Thailand showing karyotype cytotype A (telomeric NOR) and B (interstitial NOR) of Siamese catfish (Pseudomystus siamensis) from three locations (eight populations).

Table 1. Eight populations of the Siamese catfish (Pseudomystus siamensis) collected in Thailand

\begin{tabular}{|c|c|c|c|c|}
\hline \multirow{2}{*}{$\begin{array}{l}\text { Locations } \\
\text { (Province) }\end{array}$} & \multirow{2}{*}{ Populations } & \multicolumn{2}{|c|}{ Number of specimens } & \multirow{2}{*}{ Cytotypes } \\
\hline & & Male & Female & \\
\hline \multirow[t]{3}{*}{ Chi basin } & Khon Kaen & 4 & 4 & $\mathrm{~A}$ \\
\hline & Mahasarakham & 6 & 6 & $\mathrm{~A}$ \\
\hline & Roi Et & 4 & 4 & $\mathrm{~A}$ \\
\hline \multirow[t]{3}{*}{ Songkham basin } & Buang Kan & 4 & 4 & $\mathrm{~B}$ \\
\hline & Nakhon Phanom & 3 & 2 & $\mathrm{~B}$ \\
\hline & Sakon Nakhon & 4 & 5 & $\mathrm{~B}$ \\
\hline \multirow[t]{2}{*}{ Chao Phraya basin } & Singburi & 4 & 4 & $\mathrm{~B}$ \\
\hline & Ayutthaya & 4 & 4 & $\mathrm{~B}$ \\
\hline
\end{tabular}

Remarks: Cytotype A (telomeric NORs) and cytotype B (interstitial NORs). 

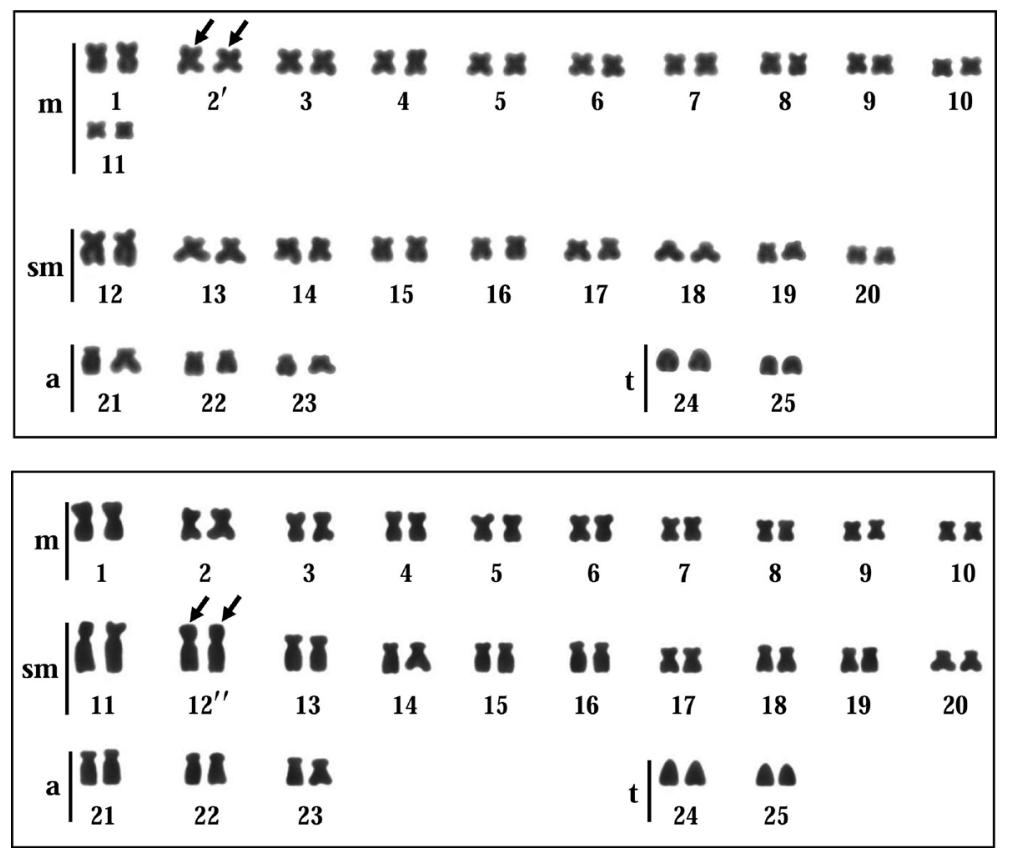

Fig. 3. Karyotypes of cytotype A (top) and cytotype B (below) of the Siamese catfish (Pseudomystus siamensis) in Thailand, $2 n=50$, by conventional staining technique. Arrows indicate homomorphism chromosome pair $2^{\prime}$ and homomorphism chromosome pair 12" resulting from paracentric inversion.

\section{Results and discussion}

Chromosome number, fundamental number and karyotype of $\mathrm{P}$. siamensis

Cytogenetic studies have been carried out on several local populations of $P$. siamensis from different locations in Thailand. The results revealed that the somatic chromosome number of $P$. siamensis is $2 n=50$ in both sexes (Fig. 3). This is in accordance with the former study of Donsakul (2002). Cytogenetic studies performed on the family Bagridae have shown a diploid chromosome number ranging from $2 n=44$ (Coreobagrus brevicorpus; Kim et al. 1982) to $2 n=80$ (Batasio havmolleri; Magtoon and Donsakul 2009). Nevertheless, the most frequent diploid chromosome number is equal to 52 chromosomes (Arai 2011). The fundamental number (NF) of P. siamensis is 96 in both male and female, which is different from the report of Donsakul (2002) who detected the NF is 86 . This difference was due to different criteria used for the classification of chromosome type is similar to other species in family Bagridae of Thailand, in that no cytologically distinguishable sex chromosome was observed. However, some bagrid catfishes in India, including M. gulio and $M$. tengara, have differentiated sex chromosome systems as $\mathrm{XX} / \mathrm{XY}$ and $\mathrm{ZZ} / \mathrm{ZW}$, respectively (Arai 2011).

The karyotypes of $P$. siamensis showed two new cytotypes for this species. The chromosomes of cytotype A consist of 22 metacentric, 18 submetacentric, 6 acrocentric, and 4 telocentric chromosomes and their frequency in the eight populations was $37.5 \%$ (three populations). Cytotype B chromosomes were composed of 20 metacentric, 20 submetacentric, 6 acrocentric, and 4 telocentric chromosomes and their frequency was $62.5 \%$ (five populations). It is inconsistent to the report of Donsakul (2002), which revealed that $P$. siamensis had the following: 20 metacentric, 16 submetacentric, 10 subtelocentric, and 4 telocentric chromosomes.

In the present study, two new cytotytes were found and the cytogenetical analyses revealed a cause of chromosomal rearrangement occurring on P. siamensis. That cause is related to paracen- 
tric inversion in one of the homologous chromosome pair $2^{\prime}$ in cytotype A (telomeric NORs) changing to the first homologous chromosome pair 12" in cytotype B (interstitial NORs). Since interstitial NORs have been found five populations (Songkham and Chao Phraya basins), they may

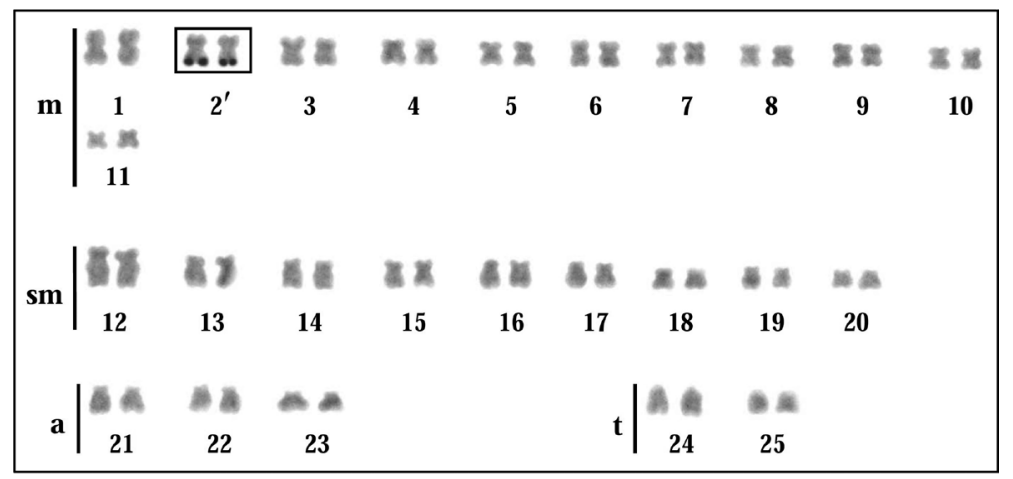

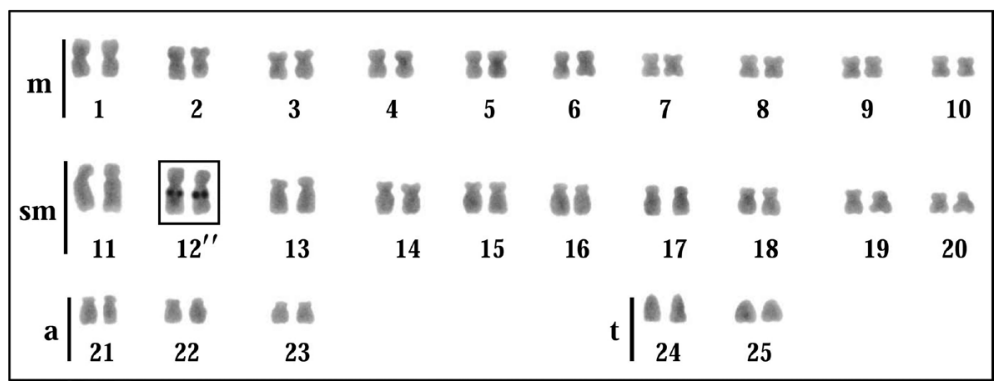

Fig. 4. Karyotypes of cytotype A (top) and cytotype B (below) of the Siamese catfish (Pseudomystus siamensis) in Thailand, $2 n=50$, by Ag-NOR banding technique. Blocks indicate homomorphism chromosome pair 2' (telomeric NORs) and homomorphism chromosome pair 12" (interstitial NORs) resulting from paracentric inversion.

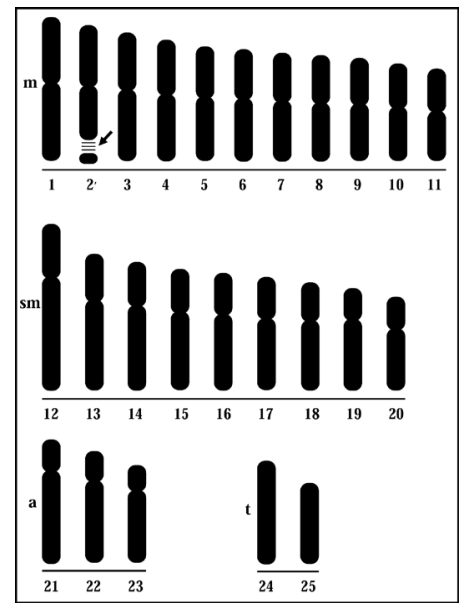

Fig. 5. Idiogram showing lengths and shapes of chromosomes cytotype A of the Siamese catfish (Pseudomystus siamensis) in Thailand, $2 n=50$, by conventional staining technique. The arrow indicates telomeric NOR-bearing chromosome pair 2'.

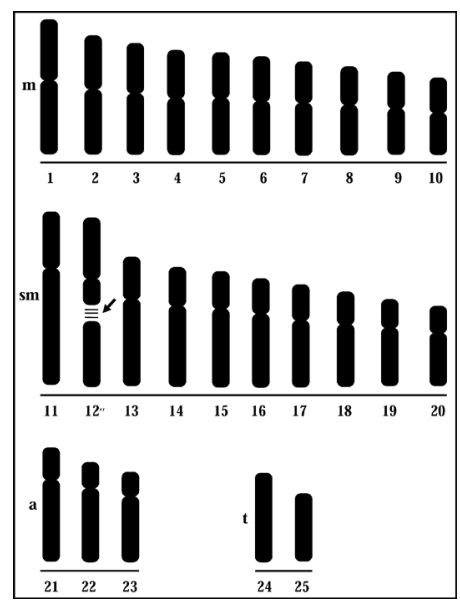

Fig. 6. Idiogram showing lengths and shapes of chromosomes cytotype B of the Siamese catfish (Pseudomystus siamensis) in Thailand, $2 n=50$, by conventional staining technique. The arrow indicates interstitial NOR-bearing chromosome pair $12^{\prime \prime}$. 
Table 2. Mean length of short arm chromosome (Ls), long arm chromosome (L1), total arm chromosome (LT), relative length (RL), centromeric index (CI) and standard deviation (SD) of RL, CI from 20 metaphases of cytotype A of the Siamese catfish (Pseudomystus siamensis) in Thailand, $2 n=50$.

\begin{tabular}{|c|c|c|c|c|c|c|c|}
\hline $\begin{array}{c}\text { Chromosome } \\
\text { pairs }\end{array}$ & Ls & $\mathrm{L} 1$ & $\mathrm{LT}$ & $\mathrm{RL} \pm \mathrm{SD}$ & $\mathrm{CI} \pm \mathrm{SD}$ & $\begin{array}{c}\text { Chromosome } \\
\text { type }\end{array}$ & $\begin{array}{c}\text { Chromosome } \\
\text { size }\end{array}$ \\
\hline 1 & 0.143 & 0.168 & 0.311 & $0.025+0.0009$ & $0.540+0.019$ & Metacentric & Large \\
\hline $2^{\prime *}$ & 0.132 & 0.162 & 0.294 & $0.023 \pm 0.0013$ & $0.546 \pm 0.018$ & Metacentric & Large \\
\hline 3 & 0.125 & 0.153 & 0.278 & $0.022 \pm 0.0008$ & $0.549 \pm 0.020$ & Metacentric & Large \\
\hline 4 & 0.119 & 0.143 & 0.262 & $0.021 \pm 0.0009$ & $0.544 \pm 0.020$ & Metacentric & Medium \\
\hline 5 & 0.112 & 0.137 & 0.249 & $0.020 \pm 0.0005$ & $0.548 \pm 0.014$ & Metacentric & Medium \\
\hline 6 & 0.109 & 0.135 & 0.244 & $0.019 \pm 0.0005$ & $0.552 \pm 0.018$ & Metacentric & Medium \\
\hline 7 & 0.108 & 0.130 & 0.238 & $0.019 \pm 0.0005$ & $0.546 \pm 0.018$ & Metacentric & Medium \\
\hline 8 & 0.104 & 0.126 & 0.230 & $0.018 \pm 0.0005$ & $0.546 \pm 0.017$ & Metacentric & Medium \\
\hline 9 & 0.102 & 0.122 & 0.224 & $0.018 \pm 0.0004$ & $0.545 \pm 0.023$ & Metacentric & Medium \\
\hline 10 & 0.097 & 0.116 & 0.213 & $0.017 \pm 0.0006$ & $0.544 \pm 0.020$ & Metacentric & Medium \\
\hline 11 & 0.091 & 0.106 & 0.197 & $0.015 \pm 0.0012$ & $0.535 \pm 0.023$ & Metacentric & Medium \\
\hline 12 & 0.116 & 0.244 & 0.360 & $0.028 \pm 0.0016$ & $0.677 \pm 0.024$ & Submetacentric & Large \\
\hline 13 & 0.103 & 0.194 & 0.297 & $0.024 \pm 0.0013$ & $0.646 \pm 0.057$ & Submetacentric & Large \\
\hline 14 & 0.096 & 0.182 & 0.278 & $0.022 \pm 0.0010$ & $0.648 \pm 0.042$ & Submetacentric & Large \\
\hline 15 & 0.095 & 0.169 & 0.264 & $0.021 \pm 0.0005$ & $0.637 \pm 0.046$ & Submetacentric & Medium \\
\hline 16 & 0.091 & 0.163 & 0.254 & $0.020 \pm 0.0008$ & $0.642 \pm 0.035$ & Submetacentric & Medium \\
\hline 17 & 0.089 & 0.154 & 0.243 & $0.019 \pm 0.0009$ & $0.626 \pm 0.049$ & Submetacentric & Medium \\
\hline 18 & 0.083 & 0.150 & 0.233 & $0.018 \pm 0.0011$ & $0.642 \pm 0.048$ & Submetacentric & Medium \\
\hline 19 & 0.069 & 0.153 & 0.222 & $0.017 \pm 0.0013$ & $0.687 \pm 0.028$ & Submetacentric & Medium \\
\hline 20 & 0.072 & 0.132 & 0.204 & $0.016 \pm 0.0012$ & $0.646 \pm 0.029$ & Submetacentric & Medium \\
\hline 21 & 0.069 & 0.200 & 0.269 & $0.021 \pm 0.0010$ & $0.738 \pm 0.046$ & Acrocentric & Large \\
\hline 22 & 0.065 & 0.176 & 0.241 & $0.019 \pm 0.0008$ & $0.725 \pm 0.024$ & Acrocentric & Medium \\
\hline 23 & 0.057 & 0.155 & 0.212 & $0.017 \pm 0.0014$ & $0.730 \pm 0.052$ & Acrocentric & Medium \\
\hline 24 & 0.000 & 0.221 & 0.221 & $0.017 \pm 0.0018$ & $1.000 \pm 0.000$ & Telocentric & Medium \\
\hline 25 & 0.000 & 0.173 & 0.173 & $0.014 \pm 0.0021$ & $1.000 \pm 0.000$ & Telocentric & Small \\
\hline
\end{tabular}

Remarks: *=NOR-bearing chromosome.

be regarded as derivatives of telomeric NORs (three populations in Chi basin) by a process of paracentric inversion (Fig. 7).

The occurrence of a local population with more than 1 cytotype has been reported for several fish species, such as those of the genus Bryconamericus (Wasko et al. 1996) and Aphanius fasciatus (Vitturi et al. 1995), in which different cytotypes had the same diploid number and different chromosome formulae. In other genera such as Corydoras (Oliveira et al. 1990, 1993), Gymnotus (Fernandes-Matioli 1996) and Hoplias (Bertollo et al. 1997), cytotypes with different diploid numbers have been described. Among 37 populations of Astyanax scabripinnis analyzed (Souza et al. 1995, Maistro et al. 1998), specimens with different diploid numbers were found in sympatry only in two, namely the populations from Canta Galo brooks (Souza et al. 1995). The karyotype formulas for P. siamensis are as stated:

Cytotype A: $2 n$ (diploid) $50=\mathrm{L}_{6}^{\mathrm{m}}+\mathrm{L}_{6}^{\mathrm{sm}}+\mathrm{L}_{2}^{\mathrm{a}}+\mathrm{M}_{16}^{\mathrm{m}}+\mathrm{M}_{12}^{\mathrm{sm}}+\mathrm{M}_{4}^{\mathrm{a}}+\mathrm{M}_{2}^{\mathrm{t}}+\mathrm{S}_{2}^{\mathrm{t}}$

Cytotype B: $2 n$ (diploid) $50=\mathrm{L}_{2}^{\mathrm{m}}+\mathrm{L}_{6}^{\mathrm{sm}}+\mathrm{M}_{14}^{\mathrm{m}}+\mathrm{M}_{12}^{\mathrm{sm}}+\mathrm{M}_{6}^{\mathrm{a}}+\mathrm{M}_{2}^{\mathrm{t}}+\mathrm{S}_{4}^{\mathrm{m}}+\mathrm{S}_{2}^{\mathrm{sm}}+\mathrm{S}_{2}^{\mathrm{t}}$ 
Table 3. Mean length of short arm chromosome (Ls), long arm chromosome (L1), total arm chromosome (LT), relative length (RL), centromeric index (CI) and standard deviation (SD) of RL, CI from 20 metaphases of cytotype B of the Siamese catfish (Pseudomystus siamensis) in Thailand, $2 n=50$.

\begin{tabular}{|c|c|c|c|c|c|c|c|}
\hline $\begin{array}{l}\text { Chromosome } \\
\text { pairs }\end{array}$ & Ls & $\mathrm{Ll}$ & LT & $\mathrm{RL} \pm \mathrm{SD}$ & $\mathrm{CI} \pm \mathrm{SD}$ & $\begin{array}{l}\text { Chromosome } \\
\text { type }\end{array}$ & $\begin{array}{c}\text { Chromosome } \\
\text { size }\end{array}$ \\
\hline 1 & 0.150 & 0.182 & 0.332 & $0.025 \pm 0.0016$ & $0.546 \pm 0.021$ & Metacentric & Large \\
\hline 2 & 0.131 & 0.160 & 0.291 & $0.022 \pm 0.0013$ & $0.550 \pm 0.027$ & Metacentric & Medium \\
\hline 3 & 0.123 & 0.151 & 0.274 & $0.021 \pm 0.0011$ & $0.552 \pm 0.025$ & Metacentric & Medium \\
\hline 4 & 0.121 & 0.139 & 0.260 & $0.020 \pm 0.0007$ & $0.535 \pm 0.016$ & Metacentric & Medium \\
\hline 5 & 0.113 & 0.139 & 0.252 & $0.019 \pm 0.0006$ & $0.553 \pm 0.021$ & Metacentric & Medium \\
\hline 6 & 0.110 & 0.133 & 0.243 & $0.018 \pm 0.0008$ & $0.549 \pm 0.025$ & Metacentric & Medium \\
\hline 7 & 0.101 & 0.129 & 0.230 & $0.017 \pm 0.0010$ & $0.559 \pm 0.029$ & Metacentric & Medium \\
\hline 8 & 0.095 & 0.123 & 0.218 & $0.016 \pm 0.0009$ & $0.565 \pm 0.027$ & Metacentric & Medium \\
\hline 9 & 0.091 & 0.114 & 0.205 & $0.015 \pm 0.0008$ & $0.559 \pm 0.027$ & Metacentric & Small \\
\hline 10 & 0.087 & 0.103 & 0.190 & $0.014 \pm 0.0010$ & $0.543 \pm 0.028$ & Metacentric & Small \\
\hline 11 & 0.140 & 0.287 & 0.427 & $0.032 \pm 0.0022$ & $0.672 \pm 0.030$ & Submetacentric & Large \\
\hline $12^{\prime \prime *}$ & 0.151 & 0.265 & 0.416 & $0.031 \pm 0.0016$ & $0.637 \pm 0.033$ & Submetacentric & Large \\
\hline 13 & 0.105 & 0.214 & 0.319 & $0.024 \pm 0.0009$ & $0.670 \pm 0.026$ & Submetacentric & Large \\
\hline 14 & 0.096 & 0.199 & 0.295 & $0.022 \pm 0.0001$ & $0.674 \pm 0.030$ & Submetacentric & Medium \\
\hline 15 & 0.093 & 0.194 & 0.287 & $0.021 \pm 0.0009$ & $0.674 \pm 0.027$ & Submetacentric & Medium \\
\hline 16 & 0.087 & 0.181 & 0.268 & $0.020 \pm 0.0010$ & $0.675 \pm 0.025$ & Submetacentric & Medium \\
\hline 17 & 0.088 & 0.166 & 0.254 & $0.019 \pm 0.0010$ & $0.653 \pm 0.030$ & Submetacentric & Medium \\
\hline 18 & 0.081 & 0.155 & 0.236 & $0.018 \pm 0.0007$ & $0.658 \pm 0.030$ & Submetacentric & Medium \\
\hline 19 & 0.072 & 0.143 & 0.215 & $0.016 \pm 0.0011$ & $0.666 \pm 0.033$ & Submetacentric & Medium \\
\hline 20 & 0.067 & 0.130 & 0.197 & $0.015 \pm 0.0012$ & $0.660 \pm 0.032$ & Submetacentric & Small \\
\hline 21 & 0.080 & 0.201 & 0.281 & $0.021 \pm 0.0015$ & $0.717 \pm 0.024$ & Acrocentric & Medium \\
\hline 22 & 0.064 & 0.181 & 0.245 & $0.018 \pm 0.0013$ & $0.741 \pm 0.023$ & Acrocentric & Medium \\
\hline 23 & 0.060 & 0.162 & 0.222 & $0.016 \pm 0.0015$ & $0.727 \pm 0.021$ & Acrocentric & Medium \\
\hline 24 & 0.000 & 0.219 & 0.219 & $0.016 \pm 0.0020$ & $1.000 \pm 0.000$ & Telocentric & Medium \\
\hline 25 & 0.000 & 0.166 & 0.166 & $0.012 \pm 0.0011$ & $1.000 \pm 0.000$ & Telocentric & Small \\
\hline
\end{tabular}

Remarks: *=NOR-bearing chromosome.

\section{Chromosome markers of $\mathrm{P}$. siamensis}

Recently, chromosomal studies on fish have been providing increasingly details information about karyotypical variability at inter- and intra-specific levels, which can be of great interest to phylogenetic, systematics and taxonomy (Centofante et al. 2002). The present study is the first report on $P$. siamensis accomplished by the Ag-NOR banding technique. The technique shows dark bands (NOR-positions) on long arms near telomere of metacentric chromosome pair 2' in cytotype A and interstitial on long arms of submetacentric chromosome pair 12" in cytotype B (Figs. 4 and 8).

Chromosomal rearrangements involving inversions have been reported in some fish species. In Ilyodon furcidens from the Coahuayana River basin in Southern Mexico, Turner et al. (1985) detected a diploid chromosome number of $2 n=48$ but with numerical variation of the metacentric chromosomes, thus identifying 4 cytotypes. In Hoplerythrinus unitaeniatus, from the Negro River, Giuliano-Caetano and Bertollo (1988) detected a number of $2 n=48$ and identified four related cytotypes with or without acrocentric chromosomes. In S. spilopleura, from the Paraná Paraguay basin, Cestari and Galetti (1992a), detected a number of $2 n=60$ identifying three cytotypes related to the 
presence of metacentric and acrocentric chromosomes, in allopatry. Nakayama et al. (2000) also observed the occurrence of two cytotypes (cytotype A and B) with equal diploid numbers $(2 n=60)$, but in sympatry at Catalão Lake for this same species. Most chromosomal inversions determine a genetic variation caused by gene segregation, and they are disadvantageous when in homozygosity.

Among piranhas, Serrasalmus might be considered the most well studied genus, in terms of chromosomal analysis. Multiple NORs systems, located on subtelo-acrocentric chromosomes, in which number, size and intensity of markings vary intra-individually, seem to be a rule (Galetti et al. 1985, Cestari and Galetti 1992a, b, Martins-Santos et al. 1994, Cestari 1996, Nakayama 1997, Centofante et al. 2002). Since variability due to chromosome rearrangements can determine change only in the chromosome structure (by deletions,

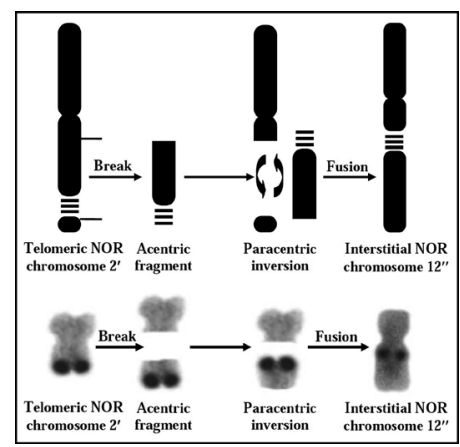

Fig. 7. The chromosome pair $12^{\prime \prime}$ cytotype B formation model of the Siamese catfish (Pseudomystus siamensis) in Thailand resulting from paracentric inversion. duplications, inversions, and/or translocations), understanding these alterations and their association to the speciation process, is a major challenge in karyoevolutionary studies (White 1977, John 1980, Guerra 1988, Centofante et al. 2002).

The important chromosome marker of the $P$. siamensis is the asymmetrical karyotype in which all four types of chromosomes (metacentric, submetacentric, acrocentric, and telocentric chromosomes) were found. The idiograms demonstrate a continuous length gradation of chromosomes (cytotype A and B). The largest and smallest chromosomes show size difference (approximately two fold). The chromosome marker

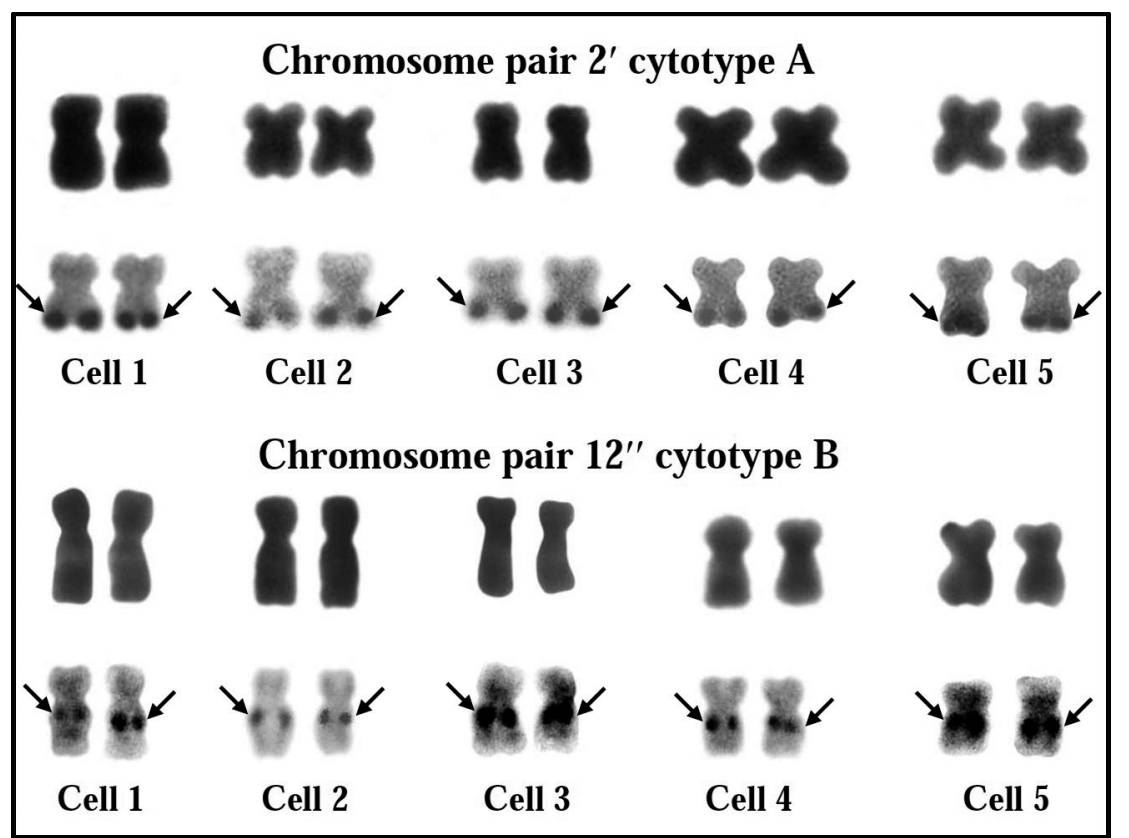

Fig. 8. 
of $P$. siamensis is chromosome pair one, which is the largest metacentric chromosome, and chromosome pair 25, which is the smallest telocentric chromosome. The data of the chromosomal checks on mitotic metaphase cells of $P$. siamensis are shown in Tables 2 and 3, and the idiograms are shown in Figs. 5 and 6.

\section{Acknowledgments}

This work was supported by the Development and Promotion of Science and Technology talents project (DPST), Applied Taxonomic Research Center (ATRC), Khon Kaen University grant; ATRC-R5304 and by a grant from the Faculty of Science, Khon Kaen University.

\section{References}

Almeida-Toledo, L. F. 2000. Karyotypic evolution in Neotropical freshwater fish. Chrom. Today 13:169-182.

Amemiya, C. T., and Gold, J. R. 1988. Chromosomal NORs taxonomic and systematic characters in North American cyprinid fishes. Genetica 76: 81-90.

Arai, R. 2011. Fish Karyotypes: A Check List. Springer Japan, Tokyo.

Bertollo, L. A. C., Moreira-Filho, O., and Fontes, M. S. 1997. Karyotypic diversity and distribution in Hoplias malabaricus (Pisces, Erythrinidae): Cytotypes with $2 n=40$ chromosomes. Rev. Bras. Genet. 20: 237-242.

Capistano, T. G., Portela-Castro, A. L. B., and Julio-Junior, H. F. 2008. Chromosome divergence and NOR polymorphism in Bryconamericus aff. iheringii (Teleostei, Characidae) in the hydrographic systems of the Paranapanema and Ivaí Rivers, Paraná, Brazil. Genet. Mol. Biol. 31: 203-207.

Centofante, L., Rebelo, J. I., and Feldberg, E. 2002. Chromosomal polymorphism in Serrasalmus spilopleura Kner, 1858 (Characidae, Serrasalminae) from central Amazon basin. Caryologia 55: 37-45.

Cestari, M. M. 1996. Estudos citogenéticos e genéticos bioquímicos em peixes do gênero Serrasalmus (Characiformes). Unpublished Ph.D. Thesis. Universidade Federal de São Carlos, São Carlos.

Cestari, M. M., and Galetti, P. M. 1992a. Chromosome studies of Serrasalmus spilopleura (Characidae, Serrasalminae) from the Paraná-Paraguai Rivers: evolutionary and cytotaxonomic considerations. Copeia 1: 108-112.

Cestari, M. M., and Galetti, P. M. 1992b. Chromosome evolution in the genus Serrasalmus and cytotaxonomic considerations about Serrasalminae (Characidae, Pisces). Rev. Bras. Genet. 15: 555-567.

Chen, T. R., and Ehbeling, A. W. 1968. Karyological evidence of female heterogamety in the mosquito fish, Gambusia affinis. Copeia. 1: 70-75.

Chaiyasut, K. 1989. Cytogenetics and cytotaxonomy of the family Zephyranthes. Department of Botany, Faculty of Science, Chulalongkorn University, Bangkok.

Donsakul, T. 2002. Chromosome study on four species of bagrid catfishes, Mystus mysticetus, Leiocassis siamensis, Bagrichthys macropterus, and B. macracanthus, from Thailand. In: Proceedings of the $40^{\text {th }}$ Kasetsart University Annual Conference: Animal, Fisheries and Science. Kasetsart University, Bangkok. pp. 681-691.

Fernandes-Matioli, F. M. C. 1996. Análises citogenéticas e dos padrões de descargas dos órgãos elétricos (DOEs) no gênero Gymnotus (Pisces, Gymnotidae). Master's thesis, Universidade de São Paulo, São Paulo.

Ferraris, C. J. 2007. Checklist of catfishes, recent and fossil (Osteichthyes: Siluriformes), and catalogue of Siluriform primary types. Zootaxa 141: 1-628.

Galetti, P. M., Silva, E. B., and Cerminaro, R. T. 1985. Multiple NOR system in fish Serrasalmus spilopleura (Serrasalminae, Characidae). Rev. Bras. Genet. 8: 479-484.

Galetti, Jr. P. M. 1998. Chromosome diversity in neotropical fish. NOR studies. Ital. J. Zool. (Modena) 65: 53-56.

Giuliano-Caetano, L., and Bertollo, L. A. C. 1988. Karyotype variability in Hoplerythrinus unitaeniatus (Characiformes, Erythrinidae). I. Chromosome polymorphism in the Rio Negro populations (Manaus, state of Amazon). Rev. Bras. Genet. 11: 299-307.

Guerra, M. 1988. Introdução à Citogenética Geral., Rio de Janeiro. pp. 82-132.

Howell, W. M., and Black, D. A. 1980. Controlled silver-staining of nucleolus organizer regions with a protective colloidal developer: a 1-step method. Experientia 36: 1014-1015.

John, B. 1980. Citogenética de populações. EDSUP, São Paulo.

Kim, D. S., Park, E. H., and Kim, J. S. 1982. Karyotypes of nine species of the Korean catfishes (Teleostomi: Siluriformes). Korean J. Genet. 4: 57-68.

Magtoon, W., and Donsakul, T. 2009. Karyotypes of five bagrid catfishes (family Bagridae): Mystus multiradiatus, M. castaneus, M. atrifasciatus, Batasio havmolleri and Sperata acicularis from Thailand. In: Proceedings of the $47^{\text {th }}$ Kasetsart University Annual Conference, Kasetsart, Fisheries. Kasetsart University, Bangkok. pp. 328-336. 
Maistro, E. L., Foresti, F., and Oliveira, C. 1998. Comparative cytogenetic and morphological analysis of Astyanax scabripinnis paranae (Pisces, Characidae, Tetragonopterinae). Genet. Mol. Biol. 21: 201-206.

Martins-Santos, I. C., Julio, Jr. H. F., and Santos, S. J. 1994. Chromosome study of two species of the genus Serrasalmus (Characidae, Serrasalminae) from the Paraná River. Cytologia 59: 175-181.

Nakayama, C. M. 1997. Caracterização cariotípica de peixes da subfamília Serrasalminae (Characiformes) da bacia amazônica. Unpublished Master thesis, Programa de Pós-Graduação em Biologia Tropical e Recursos Naturais/ BADPI. Instituto Nacional de Pesquisas da Amazônia (INPA), Manaus.

Nakayama, C. M., Porto, J. I. R., and Feldberg, E. 2000. Ocorrência de dois citótipos em Serrasalmus spilopleura Kner, 1858 (Characiformes, Serradalmidae) da região de confluência dos rios Negro e Solimões, Amazonas, Brasil. Acta Acta Amazonica. 30: 149-154.

Nanda, I., Schsrtl, M., Fiechtinger, W., Schlupp, I., Parzefall, J., and Schmid, M. 1995. Chromosomal evidence for laboratory synthesis of triploid hybrid between the gynogenetic teleost Poecilia formosa and its host species. J. Fish Biol. 47: 619-623.

Nelson, J. S. 2006. Fishes of the world. $4^{\text {th }}$ ed. John Wiley and Sons, Inc., New York.

Oliveira, C., Almeida-Toledo, L. F., and Toledo-Filho, S. A. 1990. Comparative cytogenetic analysis in three cytotypes of Corydoras nattereri (Pisces, Siluriformes, Callichthyidae). Cytologia 55: 21-26.

Oliveira, C., Almeida-Toledo, L. F., Mori, L., and Toledo-Filho, S. A. 1993. Cytogenetic and DNA content studies on armoured catfishes of the genus Corydoras (Pisces, Siluriformes, Callichthyidae) from the southeast coast of Brazil. Rev. Bras. Genet. 16: 617-629.

Rainboth, W. J. 1996. Fishes of the Cambodian Mekong. Food and Agriculture Organization of the United Nations, Rome.

Souza, I. L., Moreira-Filho, O., and Bertollo, L. A. C. 1995. Cytogenetic diversity in the Astyanax scabripinnis (Pisces, Characidae) complex. II. Different cytotypes living in sympatry. Cytologia 60: 273-281.

Turner, B. J., Grudzun, T. A., and Worrel, R. A. 1985. Extensive Chromosomal divergence within a single river basin in the goodeid fish, Iliodon furcidens. Evolution 39: 122-134.

Vidthayanon, C. 2005. Handbook of Freshwater Fish. $2^{\text {nd }}$ ed. Sarakadee Press, Bangkok.

Vitturi, R., Catalano, E., Colomba, M. S., Montagnino, L., and Pellerito, L. 1995. Karyotype analysis of Aphanius fasciatus (Pisces, Cyprinodontiformes): Ag-NORs and C-band polymorphism in four populations from Sicily. Biol Zent B1 114: 392-402.

Wasko, A. P., Venere, P. C., and Galetti, Jr. P. M. 1996. Chromosome divergences between two sympatric characid fishes of the genus Bryconamericus. Rev. Bras. Genet. 19: 225-230.

White, M. J. D. 1977. Os cromossomas. Nacional, São Paulo. pp. 25-44. 